\title{
Effects of wheat-canola intercropping on Phelipanche aegyptiaca parasitism
}

\author{
Zeynab Razavifar, Hassan Karimmojeni*, Fatemeh Ghorbani Sini \\ Department of Agronomy and Plant Breeding, College of Agriculture, Isfahan University of Technology, Isfahan, 84156-83111, Iran
}

Vol. 57, No. 3: 268-274, 2017

DOI: 10.1515/jppr-2017-0038

Received: April 23, 2017

Accepted: August 21, 2017

*Corresponding address:

kmojeni@cc.iut.ac.ir

\begin{abstract}
Parasitic weeds especially Phelipanche aegyptiaca decrease severely the production of canola. This study evaluated the effect of intercropping different wheat genotypes with canola on Phelipanche aegyptiaca growth. Ten wild wheat genotypes with different ploidy levels including TRI11712, TRI19322, TRI18664, TRI19652, TRI565, TRI15593, TRI12911, TRI11554, TRI17606, TRI7259P and seven cultivated bread wheats, namely: Falat, Chamran, Alamut, Baiat, Kavir, Sepahan, Alvand in addition to a canola cultivar called Zarfam were studied. The results revealed that intercropping of canola with wheat could significantly reduce broomrape growth depending on the type of wheat genotype. A significant genetic variation of allelopathic activity in wheat was observed, indicating the contribution of multiple genes conferring the allelopathic trait. TRI565 and TRI12911, TRI15593, TRI18664, TRI19652, TRI17606, TRI19322, and TRI7259 genotypes showed strong inhibitory effects and can be considered as potential allelopathic genotypes to suppress broomrape. The inhibitory potential of wild wheat genotypes was stronger than cultivated wheat genotypes. Alamut, Baiat, Alvand, Sepahan, and TRI11712 possessed strong stimulatory effects on broomrape germination. Such genotypes may be valuable as trap crops for depleting the Egyptian broomrape seed bank.
\end{abstract}

Key words: allelopathy, intercropping, parasitic plants, Phelipanche aegyptiaca, Striga, wheat-canola

\section{Introduction}

Canola (Brassica napus L.) is an annual or biennial herbaceous plant in the Brassicaceae family. This species has such a long history of cultivation and diversification that its origin center is not known. It may originate from a garden hybrid of $B$. olearacea var. capitata and B. rapa var. rapa (Quiros and Paterson 2004)

Since parasitic plants are not able to synthetize adequate nutrients for their development, they require a host plant to survive. Parasitic plants cause severe damage to economically important plants (Mokhtar et al. 2009; Blagojević et al. 2014).

Broomrape species (Orobanche spp. syn. Phelipanche spp.) are obligate root parasitic plants which are devoid of chlorophyll (Gauthier et al. 2012). Some are noxious parasitic weeds in important crops, including O. crenata, O. cumana, O. minor, P. aegyptiaca and P. ramosa (Amri 2013).
Phelipanche aegyptiaca poses a serious threat to host plants such as canola, carrot, lettuce, tomato, capeweed and vetch (Babaei et al. 2010). Parasitic weeds especially $P$. aegyptiaca decrease severely the production of canola.

Several approaches have been applied to control broomrapes, but none has enjoyed unequivocal success (Gauthier et al. 2012). Since the greatest damage caused by these parasites appears prior to their shoot emergence and flowering, the majority of yield loss may occur before the infection diagnosis (Babaei et al. 2010). In addition, these weeds produce thousands of minute seeds which are highly persistent in the soil and can easily be distributed to new areas (Acsoy et al. 2013). Integrated weed management is the only efficient method for broomrape control (Chittapur et al. 2001). 
Crop rotation may have direct and indirect effects on parasitic weeds in infested areas. Although trapand catch-crops in rotation may decrease the parasitic seed bank in the soil, other rotation crops may have allelopathic impacts on the seeds of parasitic weeds. Trap cropping is used to protect the main crop from the impact of parasitic weeds (Rubiales and Fernández-Aparicio 2012). It is necessary to identify potential trap crops for each species (Fernández-Aparicio et al. 2009).

Some crops have been known to have allelopathic effects. Bread wheat (Triticum aestivum L.), durum wheat (T. durum L.), barley (Hordeum vulgare L.), oats (Avena sativa L.), maize (Zea mays L.), beet (Beta vulgaris L.), lupine (Lupines lutes L.) (Rice 1984; Oueslati 2002) have been examined for differential allelopathy in sustainable weed management strategies.

Intercropping systems may demonstrate advantages for weed suppression over sole cropping in two ways. First, higher crop yield and less weed growth could be achieved if intercropping is more efficient than sole cropping in usurping resources from weeds or suppressing weed growth via allelopathy. Weed suppression in intercropping via more effective use of environmental resources by component crops has been reported in many studies (Liebman and Dyck 1993; Oleszek 1994; Mashingaizde et al. 2000; Wanic et al. 2004; Poggio 2005; Eskandari and Kazemi 2011). Second, intercropping may provide greater crop yield without weed suppression below levels observed in component sole cropping if intercropping uses resources which are not exploitable by weeds or convert resources to harvestable material more effectively than sole cropping systems (Liebman and Dyck 1993; Eskandari and Kazemi 2011).

Parker and Riches (1993) reported that the effects of intercropping on the control of Striga is due to the fact that the intercropped non-host legumes may act as trap crops, and stimulate suicidal Striga germination. Abebe et al. (2005) evaluated the effect of ten potential trap crops on the Orobanche soil seed bank and tomato yield. They reported that maize and snap bean showed better performance in stimulating the germination of Orobanche seed. Maize and snap bean also complement each other under intercropping and tomato yield increased due to the decrease of the Orobanche seed bank. According to Babaei et al. (2010), the soil seed bank of broomrape could be decreased by using trap crops such as sesame, brown Indian hemp, common flax and black-eyed pea in rotation. Ghotbi et al. (2012) determined the allelopathic potential of different crops for their abilities to stimulate P. aegyptiaca seed germination. They reported corn, oat, beet, sugar beet, triticale, caster-oil plant, millet, fiber flax, pepper, cotton and sorghum as potential trap crops for the weed P. aegyptiaca. Baumann et al. (2000) suggested that leek could be intercropped with celery (Apium graveolens L.) to improve weed suppression relative to a leek monoculture, whose open canopy structure allows weeds to proliferate. They reported that, for an intercrop of leek and celery, light interception and soil cover were increased compared with a leek monoculture, and yield reduction due to weed competition was decreased. Oswald et al. (2002) examined the effect of eight different intercrops on Striga populations and crop yield. They found that intercropping is an effective component of an integrated Striga control program. In the long run, Striga populations can only be reduced if intercropping is combined with hand weeding of mature Striga plants to avoid the replenishment of the Striga seed bank in the soil.

The objective of this study was to examine the effect of intercropping of different wheat genotypes with canola on reducing $P$. aegyptiaca damage.

\section{Materials and Methods}

\section{Plant materials}

The present study was performed on ten wild wheat genotypes with different ploidy levels (TRI11712, TRI19322, TRI18664, TRI19652, TRI565, TRI15593, TRI12911, TRI11554, TRI17606, TRI7259P) and seven cultivated bread wheats, including: Falat, Chamran, Alamut, Baiat, Kavir, Sepahan, Alvand in addition to a canola cultivar called Zarfam. Details of the genetic materials are presented in Table 1.

Table 1. Plant materials (wild and cultivated wheats) used in the study

\begin{tabular}{cccc}
\hline No. & Genotype & Chromosome No. & Code \\
\hline 1 & Alvand & 42 & TRI.1.C.Alv \\
2 & Alamut & 42 & TRI.2.C.Alm \\
3 & Baiat & 42 & TRI.3.C.Bi \\
4 & Chamran & 42 & TRI.4.C.Ch \\
5 & Sepahan & 42 & TRI.5.C.S \\
6 & Falat & 42 & TRI.6.C.F \\
7 & Kavir & 42 & TRI.7.C.C \\
8 & TRI7259 & 56 & TRI.8.W.7259 \\
9 & TRI11712 & 42 & TRI.9.W.11712 \\
10 & TRI11554 & 42 & TRI.10.W.11554 \\
11 & TRI18664 & 42 & TRI.11.W.18664 \\
12 & TRI19322 & 42 & TRI.12.W.19322 \\
13 & TRI12911 & 28 & TRl.13.W.12911 \\
14 & TRI17606 & 28 & TRI.14.W.17606 \\
15 & TRI15593 & 28 & TRI.15.W.15593 \\
16 & TRI19652 & 28 & TRI.16.W.19652 \\
17 & TRI565 & 14 & TRI.17.W.565 \\
\hline & & &
\end{tabular}




\section{Growth conditions and measurements}

Broomrape (P. aegyptiaca) seeds were collected from naturally infested canola fields. Seeds of broomrape were treated with GA3 (Merck) tobreakthedormancy.Each pot was contaminated at the rate of $25 \mathrm{mg}$ of broomrape seeds per pot. Pots $(20-\mathrm{cm}$-diameter) were filled $2 / 3$ with soil-broomrape mixture while the remaining $1 / 3$ was filled with clay and vermicompost. In the experimental group, 15 seeds of wheat and 10 seeds of canola were planted per pot and were later thinned down to 2 wheat seedlings and 1 canola seedling per pot at two-leaf stage for wheat and at four-leaf stage for canola. In the control group, only canola seeds were planted. Pots were watered every other day as needed. The plants were grown at a day/night cycle of $16 / 8 \mathrm{~h}$, at $25 / 20^{\circ} \mathrm{C}$, and at a light intensity of 12,000 LUX. Plants were fertilized with NPK fertilizer [20-20-20 + TE (trace element), $\left.1 \mathrm{~g} \cdot \mathrm{l}^{-1}\right]$ several times to avoid any nutrient deficit during the growth period. The number of broomrape stems and tubercles, the length and dry weight of the underground parts of the broomrape, and the dry weight of aerial parts were recorded at the ripening stage of canola.

\section{Statistical analysis}

The experiment was conducted in the form of a completely randomized design with 3 replications and 18 treatments. All collected data were subjected to analysis of variance (ANOVA) by SAS Ver.9.1 and mean comparisons were performed using LSD. For grouping the genotypes all data were analyzed using cluster analysis with the JMP statistic program after data standardization by the Ward method.

\section{Results}

Results of ANOVA indicated that wheat-canola intercropping significantly $(\alpha=0.01)$ affected measured traits of broomrape (Table 2).

\section{Effect of wheat-canola intercropping on the growth of broomrape}

\section{Number of broomrape stems}

The control treatment produced 4.66 broomrape stems, while the highest number of broomrape stems at the soil surface was found in Alvand-canola intercropping, which was 7.33 (Table 3). Alvand, Sepahan, Alamut, Baiat, and TRI11712 were categorized in the same statistical group in terms of this trait. The least number of stems was observed in Chamran-canola intercropping (3.66), which was classified in the same group as Falat, TRI18664 and TRI15593. The Chamran genotype had the greatest inhibitory effect on this trait. No broomrape stems were found at the soil surface of TRI12911and TRI 565-canola intercropping. Hence, these two genotypes had strong inhibitory effects.

\section{Number of broomrape tubercles}

Control treatment produced 2.66 broomrape stems, while the maximum number of broomrape tubercles was observed in Baiat-canola intercropping (4.66). This genotype was classified in the same statistical group as: Alamut, Sepahan, Alvand, TRI11712 and TRI11554 in terms of the number of tubercles. Broomrape produces more tubercles in the presence of some genotypes which release more chemicals with the ability to stimulate broomrape germination. The greater number of broomrape tubercles means further growth of broomrape and more attachments of this species to near-by canola. The minimum number of tubercles was found in TRI19322-canola intercropping. TRI19322, Falat, TRI17606, TRI7259, TRI15593, and TRI18664 were classified in the same statistical group. No tubercles were detected in TRI565- and TRI12911-intercropping (Table 3). Thus, broomrape germination was completely inhibited by these two genotypes.

\section{Length of broomrape underground parts}

The length of broomrape underground parts was $(5.53 \mathrm{~cm})$ in sole culture of canola (control treatment). The highest length of broomrape underground parts $(7.26 \mathrm{~cm})$ was found when Sepahan genotype was intercropped with canola, and the lowest broomrape root length $(1.43 \mathrm{~cm})$ occurred in TRI7259-canola intercropping (Table 3).

\section{Dry weight of broomrape underground parts}

While intercropping Baiat genotype with canola led to the highest dry weight of broomrape underground parts $\left(0.673 \mathrm{~g} \cdot\right.$ pot $\left.^{-1}\right)$, TRI15593 caused the lowest amount $\left(0.113 \mathrm{~g} \cdot\right.$ pot $\left.^{-1}\right)$. TRI15593, TRI7259, and TRI19652 were placed in the same statistical group in terms of this trait (Table 3 ). The dry weight of broomrape underground parts was $\left(0.346 \mathrm{~g} \cdot\right.$ pot $\left.^{-1}\right)$ in sole culture of canola.

\section{Dry weight of broomrape aerial parts}

The highest and the lowest dry weights of broomrape aerial parts were produced by Alvand- and Chamran-canola intercropping, which were 0.626 and $0.21\left(\mathrm{~g} \cdot \mathrm{pot}^{-1}\right)$, respectively. Chamran, TRI7259, TRI15593, and TRI19322 genotypes were classified in the same statistical group in terms of this trait (Table 3).

\section{Orthogonal contrasts}

According to orthogonal contrasts results (Table 3), there were no significant differences between wild and 
Table 2. Analysis of variance results for effects of wheat-canola intercropping on broomrape traits. Mean square values are presented for each variable

\begin{tabular}{|c|c|c|c|c|c|c|}
\hline Source of variation & $\begin{array}{l}\text { Degree } \\
\text { of freedom }\end{array}$ & $\begin{array}{l}\text { Stem } \\
\text { No. }\end{array}$ & $\begin{array}{l}\text { Tubercle } \\
\text { No. }\end{array}$ & $\begin{array}{c}\text { Length } \\
\text { of underground } \\
\text { part }\end{array}$ & $\begin{array}{c}\text { Dry weight } \\
\text { of underground } \\
\text { part }\end{array}$ & $\begin{array}{l}\text { Dry weight } \\
\text { of aerial part }\end{array}$ \\
\hline Treatment & 15 & $7.088^{* *}$ & $3.22^{* *}$ & $7.86^{* *}$ & $0.0749 * *$ & $0.0476^{* *}$ \\
\hline $\begin{array}{l}\text { Comparison } \\
\text { of wild wheats }\end{array}$ & 6 & - & - & - & - & - \\
\hline $\begin{array}{l}\text { Comparison } \\
\text { of cultivated wheats }\end{array}$ & 7 & - & - & - & - & - \\
\hline $\begin{array}{l}\text { Cultivated wheats } \\
\text { compared to wild wheats }\end{array}$ & 1 & $6.816 \mathrm{~ns}$ & $5.08^{*}$ & $26.821^{* *}$ & $0.000054 \mathrm{~ns}$ & $0.0138 \mathrm{~ns}$ \\
\hline Error & 32 & 0.645 & 0.458 & 0.048 & 0.0025 & 0.00075 \\
\hline CV\% & - & 16.91 & 22.41 & 4.716 & 14.33 & 7.62 \\
\hline
\end{tabular}

${ }^{*}$ significant at $5 \%$ probability level, ${ }^{* *}$ significant at the $1 \%$ probability level, ns - not significant, CV - coefficient of variance

Table 3. Effect of wheat-canola intercropping on broomrape traits

\begin{tabular}{|c|c|c|c|c|c|c|}
\hline $\begin{array}{l}\text { Wild and } \\
\text { cultivated } \\
\text { wheats }\end{array}$ & Genotype & $\begin{array}{l}\text { Stem } \\
\text { No. }\end{array}$ & $\begin{array}{c}\text { Tubercle } \\
\text { No. }\end{array}$ & $\begin{array}{l}\text { Length } \\
\text { of underground } \\
\text { part }\left[\mathrm{cm} \cdot \text { pot }^{-1}\right]\end{array}$ & $\begin{array}{l}\text { Dry weight } \\
\text { of underground } \\
\text { part }\left[\mathrm{cm} \cdot \text { pot }^{-1}\right]\end{array}$ & $\begin{array}{c}\text { Dry weight } \\
\text { of aerial part } \\
{\left[\mathrm{g} \cdot \mathrm{pot}^{-1}\right]}\end{array}$ \\
\hline \multirow{7}{*}{$\begin{array}{l}\text { Cultivated } \\
\text { wheats }\end{array}$} & TRI.1.C.Alv & $7.33 \mathrm{a}$ & $4 a b$ & $6 c$ & $0.536 b$ & $0.626 a$ \\
\hline & TRI.2.C.Alm & $6.66 a$ & $4.33 \mathrm{ab}$ & $6.13 c$ & $0.41 \mathrm{~cd}$ & $0.52 \mathrm{~b}$ \\
\hline & TRI.3.C.Bi & $6 a b$ & $4.66 \mathrm{a}$ & $6.3 c$ & $0.673 a$ & $0.453 c$ \\
\hline & TRI.4.C.Ch & $3.66 \mathrm{cde}$ & $3.33 \mathrm{bcd}$ & $5.26 \mathrm{~d}$ & $0.486 \mathrm{bc}$ & $0.21 \mathrm{i}$ \\
\hline & TRI.5.C.S & $7 a$ & $4.33 \mathrm{ab}$ & $7.26 \mathrm{a}$ & $0.470 \mathrm{bc}$ & $0.556 \mathrm{~b}$ \\
\hline & TRI.6.C.F & 3 de & 2.33 def & $6.83 \mathrm{~b}$ & 0.32 ef & $0.293 \mathrm{f}$ \\
\hline & TRI.7.C.C & $4.66 \mathrm{bc}$ & $2.66 \mathrm{cde}$ & $4.5 \mathrm{e}$ & 0.283 ef & $0.28 \mathrm{fg}$ \\
\hline \multicolumn{2}{|c|}{ Cultivated wheats mean } & $5.47 \mathrm{a}$ & $4.66 \mathrm{a}$ & $6.08 \mathrm{a}$ & $0.452 \mathrm{a}$ & $0.4 \mathrm{a}$ \\
\hline \multirow{10}{*}{ Wild wheats } & TRI.8.W.7259 & $2.33 \mathrm{e}$ & 2 ef & $1.43 \mathrm{i}$ & $0.123 \mathrm{~h}$ & $0.233 \mathrm{hi}$ \\
\hline & TRI.9.W.11712 & $6.66 a$ & $4 a b$ & $4.06 \mathrm{f}$ & $0.536 \mathrm{~b}$ & 0.383 de \\
\hline & TRI.10.W.11554 & $4.33 \mathrm{~cd}$ & $3.66 a b c$ & $4.63 \mathrm{e}$ & $0.243 \mathrm{fg}$ & $0.26 \mathrm{fgh}$ \\
\hline & TRI.11.W.18664 & $3.33 \mathrm{cde}$ & 2.33 def & $3.56 \mathrm{~g}$ & $0.236 \mathrm{fg}$ & $0.386 \mathrm{de}$ \\
\hline & TRI.12.W.19322 & $4.33 \mathrm{~cd}$ & $1.33 \mathrm{f}$ & $3.96 \mathrm{f}$ & $0.346 \mathrm{de}$ & $0.246 \mathrm{ghi}$ \\
\hline & TRI.13.W.12911 & - & - & - & - & - \\
\hline & TRI.14.W.17606 & $4.33 \mathrm{~cd}$ & $1.66 \mathrm{ef}$ & $3.03 \mathrm{~h}$ & 0.333 de & $0.303 \mathrm{f}$ \\
\hline & TRI.15.W.15593 & $3.33 \mathrm{cde}$ & 2.33 def & $3.2 \mathrm{~h}$ & $0.113 \mathrm{~h}$ & $0.243 \mathrm{ghi}$ \\
\hline & TRI.16.W.19652 & $4.33 \mathrm{~cd}$ & $2.66 \mathrm{cde}$ & $3 \mathrm{~h}$ & $0.186 \mathrm{gh}$ & $0.423 \mathrm{~cd}$ \\
\hline & TRI.17.W.565 & - & - & - & - & - \\
\hline \multicolumn{2}{|c|}{ Wild wheats mean } & $4.12 \mathrm{a}$ & $2.49 \mathrm{~b}$ & $3.35 \mathrm{~b}$ & $0.45 a$ & $0.339 a$ \\
\hline Control & Can.18.ZA & $4.66 b c$ & $2.66 \mathrm{cde}$ & $5.53 \mathrm{~d}$ & 0.346 de & $0.353 \mathrm{e}$ \\
\hline
\end{tabular}

In each column, means which have similar letters do not have significant difference based on LSD test

cultivated wheat genotypes in terms of the number of broomrape stems at the soil surface, the dry weight of broomrape underground parts, and the dry weight of broomrape aerial parts. However, significant differences were detected between them in terms of the number of broomrape tubercles and the length of broomrape underground parts at $1 \%$ and $5 \%$ probability levels, respectively. In general, the inhibitory potential of wild wheat genotypes was stronger than cultivated wheat genotypes (Table 3). 


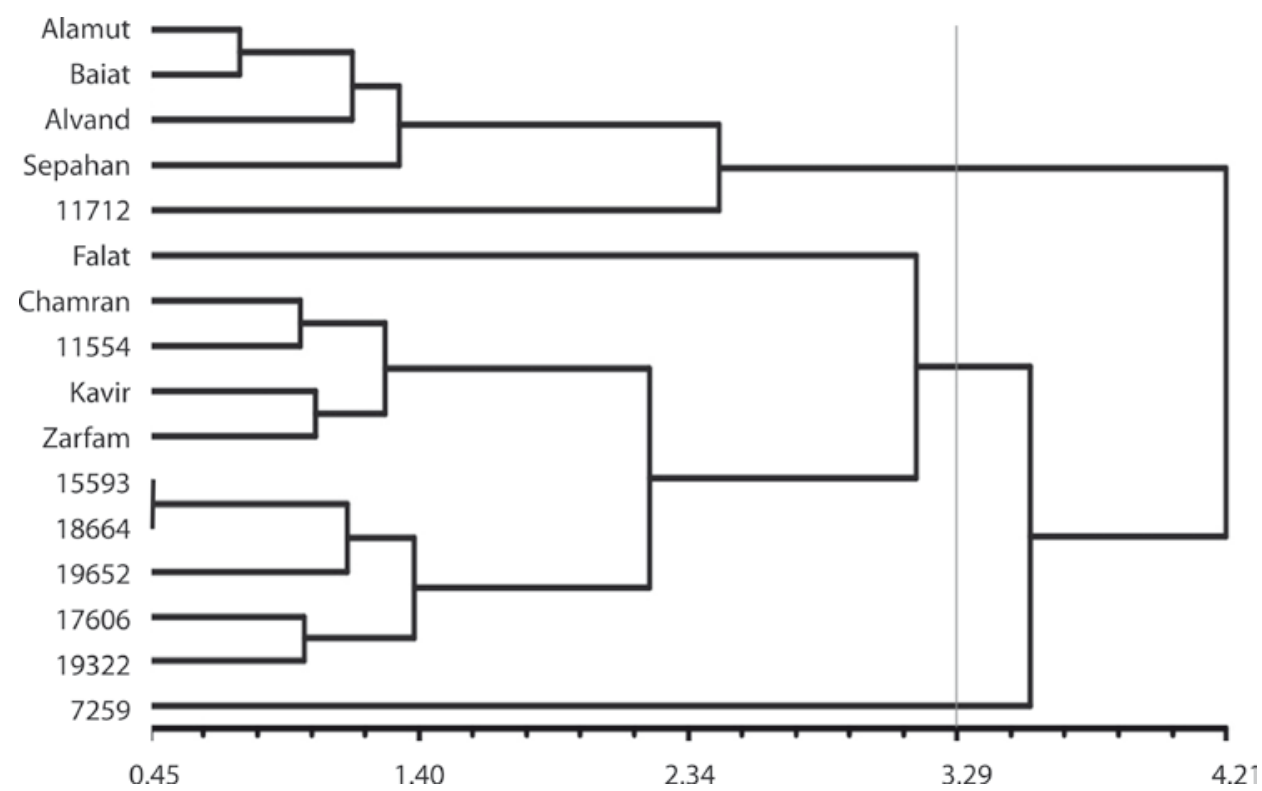

Fig. 1. Cluster analysis of wheat genotypes based on their allelopathic effects on measured traits of broomrape in wheat-canola intercropping

\section{Classification of wheat genotypes}

Cluster analysis divided the genotypes into four groups (Fig. 1): 1 - Alamut, Baiat, Alvand, Sepahan, and TRI11712 with no inhibitory effect on broomrape and with stimulatory effect on most measured traits, 2 - Falat variety with slight stimulatory effect on broomrape, and 3 - this group consisted of 2 subgroups. The 1 subgroup included Zarfam monoculture, Chamran, Kavir, and TRI11554 with no impact on broomrape; and the 2 subgroup contained wild varieties, TRI18664, TRI19652, TRI17606, and TRI19322 with intermediate inhibitory effects, 4 - TRI7259 with a significant inhibitory effect on broomrape traits. No broomrape and tubercles were found in TRI565- and TRI12911-canola intercropping. Hence, these two genotypes are not present in the diagram. According to the results of this study, TRI565 and TRI12911 were genotypes with the highest inhibitory effects against broomrape.

\section{Discussion}

The findings indicated that intercropping of canola with wheat could significantly reduce broomrape growth depending on the type of wheat genotype. The results of our research are consistent with Naeem et al. (2012), who evaluated intercropping of wheat with canola under varied spatial arrangements for their effects on weeds and reported that all treatments significantly reduced weed density and dry weight more than a sole crop of wheat. Similarly, Liebman and Dyck (1993) found that weed population density and biomass production may be significantly decreased using crop rotation and intercropping strategies. In another research, Babaei et al. (2010) reported that sesame, common flax, and black-eyed pea led to high control of broomrape so that broomrape biomass was reduced by $86,85.3,57.2$, and $74.4 \%$, respectively, compared to the control (tomato monoculture).

The results confirmed that there was considerable genetic variation in broomrape germination and growth inhibitory activity of wheat germplasm. The results of the current study are broadly in agreement with those of Wu et al. $(2000,2001)$, who also found a significant genetic variation of weed growth inhibitory activity in wheat and reported that wheat allelopathic activity is genetically controlled, and a multigenic model is involved in wheat allelopathy.

TRI565 and TRI12911 were identified as the genotypes with strong inhibitory potential to suppress broomrape. Also, TRI15593, TRI18664, TRI19652, TRI17606, TRI19322, and TRI7259 genotypes showed relatively high inhibitory effects. These genotypes can be considered as potential allelopathic genotypes to suppress broomrape. Our results are in agreement with Fernández-Aparicio et al. (2007), who demonstrated that intercropping with cereals decreases infection by O. crenata in legumes, and allelochemicals released by cereal roots inhibited $O$. crenata seed germination. A limiting effect of intercropping on the number and biomass of weeds has been reported by a number of researchers (Carruthers et al. 1998; Poggio 2005; Amanullah et al. 2006; Banik et al. 2006; Gharineh and Moosavi 2010; Eskandari and Kazemi 2011).

Since Alamut, Baiat, Alvand, Sepahan, and TRI1 1712 possessed weak inhibitory effects and strong stimulatory 
effects on broomrape germination, they can be applied as trap crops in rotation with broomrape hosts. Using trap crops to deplete soil seed banks of parasitic weeds has been reported in several studies (Carson et al. 1989; Linke et al. 1993; Parker and Riches 1993; Kliefeld et al. 1994; Carsky et al. 1994; Muscolo et al. 2001; Abebe et al. 2005; Babaei et al. 2010; Ghotbi et al. 2012). Most of broomrape traits were reduced more in response to wild wheats compared to cultivated wheats. Hence, it could be concluded that wild wheat genotypes possessed strong inhibitory effects against broomrape. Hence, the results of this study suggest using wild wheat genotypes to suppress weeds in intercropping strategies of canola production.

Considerable genetic variation was found among the studied wheat genotypes in terms of allelopathic potential, which may permit selecting more allelopathic cultivars to be applied against broomrape. Identification of the composition of chemicals released from these genotypes, especially wild wheat genotypes, may provide more opportunities for applying reliable intercropping and rotation systems and new strategies in suppressing this parasitic weed.

\section{Acknowledgements}

This work was supported by the research council of Isfahan University of Technology.

\section{References}

Abebe G., Sahile G., Altawaha A.R.M. 2005. Evaluation of potential trap crops on Orobanche soil seed bank and tomato yield in the central rift valley of Ethiopia. World Journal of Agricultural Sciences 1 (2): 148-151.

Acsoy E., Filiz Arsalan Z., Öztürk N. 2013. Phelipanche aegyptiaca (Pers.) Pomel: A new record as a parasitic weed on apricot root in Turkey. African Journal of Agricultural Research 8 (29): 4002-4006. DOI: 1 10.5897/AJAR2013.6639

Amanullah M.M., Alagesan A., Vaiyapui K., Sathyamoorthi K., Pazhanivelan S. 2006. Effect of intercropping and organic manures on weed control and performance of cassava (Manihot esculenta Cranz). Journal of Agronomy 5 (4): 589-595. DOI: https://doi.org/10.3923/ja.2006.589.594

Amri M. 2013. First report of the parasitic plant Phelipanche ramosa on berseem clover (Trifolium alexandrinum) in Tunisia. Tunisian Journal of Plant Protection 8: 127-132.

Babaei S., Alizadeh H., Jahansouz R., Rahimian H., Minbashi Moeini M. 2010. Management of Phelipanche aegyptiaca Pomel. using trap crops in rotation with tomato (Solanum lycopersicom L.). Australian Journal of Crop Science 4 (6): 437-442.

Banik P., Midya A., Sarkar B.K., Ghose S.S. 2006. Wheat and chickpea intercropping systems in an additive experiment: Advantages and weed smothering. European Journal of Agronomy 24 (4): 325-332. DOI: https://doi.org/10.1016/j. eja.2005.10.010

Blagojević M., Konstantinović B., Samardžić N., Popov M., Konstantinović B. 2014. Biological characteristics of some parasitic flowering plants. Herbologia 14 (2): 71-80.

Baumann D.T., Kropff M.J., Bastiaans L. 2000. Intercropping leeks to suppress weeds. Weed Research 40 (4): 361-376. DOI: https://doi.org/10.1046/j.1365-3180.2000.00197.x
Carruthers K., Fe Q., Cloutier D., Smith D.L. 1998. Intercropping corn with soybean, lupin and forages: Weed control by intercrops combined with inter row cultivation. European Journal of Agronomy 8 (3-4): 225-238. DOI: https://doi. org/10.1016/s1161-0301(97)00062-2

Carson A.G. 1989. Effect of intercropping sorghum and ground nuts on density of Striga hermonthica in the Gambia. Tropical Pest Management 35 (2): 130-132. DOI: https://doi. org/10.1080/09670878909371340

Chittapur B.M., Hunshal C.S., Shenoy H. 2001. Allelopathy in parasitic weeds management: Role of catch and trap crops. Allelopathy Journal 8: 147-160.

Carsky R.J., Singh L. and Ndikawa R. 1994. Suppression of Striga hermonthica on sorghum using a cowpea intercrop. Experimental Agriculture 30 (03): 349-358. DOI: https:// doi.org/10.1017/s0014479700024467

Eskandari H., Kazemi K. 2011. Weed control in maize-cowpea intercropping system related to environmental resources consumption. Notulae Scientia Biologicae 3 (1): 57-60. DOI: http://dx.doi.org/10.15835/nsb315609

Fernández-Aparicio M., Sillero J.C., Rubiales D. 2007. Intercropping with cereals reduces infection by Orobanche crenata in legumes. Crop Protection 26 (8): 1166-1172. DOI: https://doi.org/10.1016/j.cropro.2006.10.012

Fernández-Aparicio M., Flores F., Rubiales D. 2009. Recognition of root exudates by seeds of broomrape (Orobanche and Phelipanche) species. Annals of Botany 103 (3): 423-431. DOI: https://doi.org/10.1093/aob/mcn236

Gauthier M., Véronési C., El.Halmouch Y., Leflon M., Jestin C., Labalette F., Simier P., Delourme R., Delavault P. 2012. Characterisation of resistence to branched broomrape, Phelipanche ramosa, in winter oilseed rape. Crop Protection 42: 56-63. DOI: https://doi.org/10.1016/j.cropro. 2012.07.002

Gharineh M.H., Moosavi S.A. 2010. Effects of intercropping (canola-faba bean) on density and diversity of weeds. Notulae Scientia Biologicae 2 (4): 109-112. DOI: http://dx.doi. org/10.15835/nsb213612

Ghotbi M., Rouhi H.R., Amini Dehaghi M., Ghotbi M., Moghaddam Khamseh A.R. 2012. Mitigate Phelipanche aegyptiaca Pers. infestation considering natural environment conservation. International Journal of AgriScience 2 (1): 62-77.

Kliefeld Y., Goldwasser Y., Herzlinger G., Joel D.M., Golan S., Kahana D. 1994. The effect of flax (Linum usitatissimum L.) and other crops as trap and catch crops for control of Egyptian broomrape (Orobanche aegyptiaca Pers.). Weed Research 34 (1): 37-44. DOI: https://doi.org/10.1111/j.13653180.1994.tb01971.x

Liebman M., Dyck E. 1993. Crop rotation and intercropping strategies for weed management. Ecological Applications 3 (1): 92-122. DOI: https://doi.org/10.2307/1941795

Linke K.H., AbdelMoneim A.M., Saxena M.C. 1993. Variation in resistance of some forage legume species to Orobanche crenata Forsk. Field Crops Research 32 (3-4): 277-285. DOI: https://doi.org/10.1016/0378-4290(93)90037-n

Mashingaizde A.B., Nyakanda C., Chivinge O.A., Washaireni A.M., Dube K.W. 2000. Influence of a maize pumpkin live much on weed dynamics and maize yield. African Plant Protection 6 (1): 57-63.

Mokhtar M., Abdel K., Nehal S.E.M. 2009. Prospects of mycoherbicides for control of broomrapes (Orobanche spp.) in Egypt. Journal Plant Protection Research 49 (1): 64-74. DOI: https://doi.org/10.2478/v10045-009-0009-1

Muscolo A., Panuccio M.R., Sidari M. 2001. The effect of phenols on respiratory enzymes in seed germination. Respiratory enzyme activities during germination of Pinus laricio seeds treated with phenols extracted from different forest soils. Plant Growth Regulation 35: 31-35.

Naeem M., Zahid A.C., Ahmad A., Abdul W., Kamaran M., Arif M. 2012. Weed dynamics in wheat-canola intercrop- 
ping systems. Chilean Journal of Agricultural Research 72 (3): 434-439. DOI: https://doi.org/10.4067/s071858392012000300019

Oleszek K. 1994. Brassicacea as alternative plants for weed control in sustainable agiculture. Fragmenta Agronomica 4 (44): 5-15.

Oswald A., Ransom J.K., Kroschel J., Sauerborn J. 2002. Intercropping controls Striga in maize based farming systems. Crop Protection 21 (6): 367-374. DOI: https://doi. org/10.1016/s0261-2194(01)00104-1

Oueslati O. 2002. Allelopathy in two durum wheat (Triticum durum L.) varieties. Agriculture Ecosystems \& Environment 96 (1-3): 161-163. DOI: https://doi.org/10.1016/ s0167-8809(02)00201-3

Parker C., Riches C.R. 1993. Parasitic Weeds of the World: Biology and Control. CAB International, Wallingford, UK, $332 \mathrm{pp}$.

Poggio S.L. 2005. Structure of weed communities occurring in monoculture and intercropping of field pea and barley. Agriculture Ecosystems \& Environment 109 (1-2): 48-58. DOI: https://doi.org/10.1016/j.agee.2005.02.019

Quiros C.F., Paterson A.H. 2004. Genome mapping and analysis. p. 31-42. In: "Biotechnology in Agriculture and
Forestry" (E.C. Pua, C.J. Douglas, eds). Vol. 54. SpringerVerlag, Berlin-Heidelberg-New York. DOI: https://doi. org/10.1007/978-3-662-06164-0_3

Rice E.L. 1984. Allelopathy. 2nd ed. Academic Press, Orlando, FL, USA, $422 \mathrm{pp}$.

Rubiales D., Fernández-Aparicio M. 2012. Innovation in parasitic weeds management in legume crops. A review. Agronomy for Sustainable Development 32 (2): 433-449. DOI: https://doi.org/10.1007/s13593-011-0045-x

Wanic M., Kostrzewska M., Jastrzebska M. 2004. Role of intercrop sowing in weeds control for spring barley in cereal crops rotation. Fragmenta Agronomica 1 (81): 85-102.

Wu H., Pratley J., Lemerle D., Haig T. 2000. Evaluation of seedling allelopathy in 453 wheat (Triticum aestivum) accessions against annual ryegrass (Lolium rigidum) by the equal compartment-agar method. Australian Journal of Agricultural Research 51 (7): 937-944. DOI: https://doi.org/10.1071/ AR00017

Wu H., Pratley J., Lemerle D., Haig T. 2001. Allelopathy in wheat (Triticum aestivum). Annals of Applied Biology 39 (1): 1-9. DOI: https://doi.org/10.1111/j.1744-7348.2001. tb00124.x 